\title{
Impact of Front Line Demonstration on the Yield and Economics of Soybean crop in Shajapur District of Madhya Pradesh, India
}

\author{
N. S. Khedkar ${ }^{1}$, S. S. Dhakad ${ }^{2 *}$, Chandrika Sharma ${ }^{1}$, Gayatri Verma ${ }^{2}$, \\ R. F. Ahirwar ${ }^{1}$ and G. R. Ambawatia ${ }^{3}$ \\ ${ }^{1} J N K V V$ College of Agriculture, Ganjbasoda (M.P), India \\ ${ }^{2} R V S K V V$, Krishi Vigyan Kendra, Shajapur (M.P), India \\ ${ }^{3} R V S K V V$ College of Agriculture, Indore (M.P), India \\ *Corresponding author
}

\section{A B S T R A C T}

\begin{tabular}{|l|}
\hline K e y w o r d s \\
Front line \\
demonstrations, \\
Soybean, \\
Technology gap, \\
Extension gap, \\
BC ratio
\end{tabular}

Keywords

Front line

demonstrations,

Soybean,

Technology gap,

Extension gap,

$\mathrm{BC}$ ratio

\section{Introduction}

Soybean [Glycine $\max$ (L.) Merill], also known as golden and wonder and wonder bean due to presence of $40-44 \%$ protein, $20 \%$ oil and 5\% lysine. It belongs to oilseed group and occupied third place among oilseed crops in Madhya Pradesh. Being known as 'Soya State', Madhya Pradesh contributes 54.00 lakh hectare area, 45.50 lakh tonnes production and $1310 \mathrm{~kg} / \mathrm{ha}$ productivity to
Front line demonstrations on soybean were organized consecutively for three years in kharif seasons of 2014-15, 2015-16 and 2016-17 under the operational area Krishi Vigyan Kendra, Shajapur village namely Bhadoni, Gopipur, Loharwas, Tilawadgovind and Girwar in Shajapur district of Madhya Pradesh. The package of improved practices demonstrated, including variety JS 95-60, integrated nutrient management (@ 20:60:20:20:: $\mathrm{N}: \mathrm{P} 2 \mathrm{O} 5: \mathrm{K} 2 \mathrm{O}: \mathrm{S} \mathrm{kg} / \mathrm{hac}+$ rhizobium @ $5 \mathrm{~g} / \mathrm{kg}+\mathrm{PSB} 5 \mathrm{~g} / \mathrm{kg}$ of seed) integrated pest management (deep ploughing during Aprial + seed treatment with Trichoderma virde @ 5 $\mathrm{g} / \mathrm{kg}$ seed + trizophos @ $750 \mathrm{ml}$ ) and sowing on ridge and furrow method. The results revealed that the FLD recorded higher yield as compared to farmers practice over the year study. The improved technology recorded average yield of $1638 \mathrm{~kg} / \mathrm{ha}$ which was 26.97 percent higher than that obtained with farmers practice of $1305 \mathrm{~kg} / \mathrm{ha}$. The improved technology gave higher gross return of Rs/ha 50032, net return of Rs/ha 28915 with benefit cost ratio 2.41 as compared to the farmers practice give low gross return of Rs/ha 39798, net return of Rs/ha 19648 with benefit cost ratio 2 . 
universities in order to transfer the particular technology and get feedback from the farmers with respect to its feasibility, acceptability, profitability, adoptability etc. The feedback will help the scientists to reorient their research programmes as well as refinement of the technology as per the need of the farmers. Field demonstrations are an effective way to disseminate the latest technology among the farming community (Gautam et al., 2007). The scientist and farmers are concern with the low productivity of Soybean under present agro situations. In order to overcome these problems it is needed to educate and bring out the facts of the cultivation practices in the notice of the farmers through demonstration of improved production technology at their field so that they may augment technology based on seeing is believing it will develop the faith among the growers (Singh et al., 2018). Thus, keeping the above views in mind and realizing the importance of FLD in dissemination of technology the study was carried out to know the effect of demonstration conducted at different locations on the production and profitability of the farmers.

\section{Materials and Methods}

KVK Shajapur organized 36 FLDs (0.4 ha each) during three consecutive in kharif 2014 to 2016 on improved package of practices on farmers fields in adopted villages namely, Bhadoni, Gopipur, Loharwas, Tilawadgovind and Girwar of Shajapur district through the information generated from Participatory Rural Appraisal (PRA). The package of improved practices demonstrated encompassed a new variety of soybean (JS 95-60), integrated nutrient management (@ 20: 60: 20: 20:: N: P2O5: K2O: S kg/ha + rhizobium @ 5g/kg seed + PSB @ $5 \mathrm{~g} / \mathrm{kg}$ of seed), integrated pest management (deep ploughing during April + seed treatment with Trichoderma virde @ $5 \mathrm{~g} / \mathrm{kg}$ seed + trizophos
@ $750 \mathrm{ml} / \mathrm{ha}$ ) and sowing on ridge and furrow method. With row to row spacing of $30 \mathrm{~cm}$ and using seed @ 80 kg per ha, soybean crop was sown between 25th June to 10th July. An entire dose of NPK and sulphur through $\mathrm{ZnSO} 4$ was applied as basal before sowing. Under farmers practice existing variety JS 335 , was planted on ridge and furrow method without any seed treatment with fungicides and biofertilizers, using higher seed rate (110$120 \mathrm{~kg} / \mathrm{ha}$ ), broadcasting of DAP at 20 days after sowing (DAS), and following injudicious use of insecticide and weedicide. Training was imparted to the farmers of respective villages with respect to envisaged technological interventions before conducting the demonstrations (Bhargava et al., 2015). Site selection, farmer's selection, layout of demonstration and farmers participation were considered according to Choudhury (1999). Other parameters like harvest index, technology gap, extension gap and technology index $(\%)$ were worked out as suggested by Kadian et al., (1997) using following formulae.

Technology gap $(\mathrm{kg} / \mathrm{ha})=$ Potential yield Demonstration yield

Extension gap $(\mathrm{kg} / \mathrm{ha})=$ Demonstration yield - Farmers yield

$$
\text { Technology index }(\%)=\frac{\text { Potential yield }- \text { Demonstration yield }}{\text { Potential yield }} \times 100
$$

The economic analysis was done by working out cost of cultivation utilizing the inputs and output prices of commodities which prevailed during three years of demonstration, gross and net returns, and benefit cost ratio.

\section{Results and Discussion}

The results revealed that the seed yield of soybean recorded was in the range of 1360 to $1820 \mathrm{~kg}$ per ha (average $1638 \mathrm{~kg} / \mathrm{ha}$ ) by 
adoption of improved package of practices as compared to farmer's practice of 976 to 1500 $\mathrm{kg}$ per ha (average $1305 \mathrm{~kg} / \mathrm{ha}$ ). In comparison to farmer's practice, an increase of 20.58 to 39.00 per cent (average $26.97 \%$ ) in seed yield was recorded during the study period due to improved package of practices. The technological gap were found 180, 640, and $267 \mathrm{~kg}$ per ha during the year 2014, 2015 and 2016, respectively with an average of 362 $\mathrm{kg}$ per ha (Table 1). The technology gap observed may be attributed to dissimilarity in the soil fertility status and local climatic conditions. Similarly extensions gap of 320 ,
384 and $294 \mathrm{~kg}$ per ha were observed during 2014, 2015 and 2016, respectively. On an average the extension gap was observed 333 $\mathrm{kg}$ per ha, which emphasized the need to educate the farmers through various extension activities for adoption of improved agricultural production to narrow it. The technology index varied from 9.00, 32.00 and 13.35 per cent with an average of 18.11 per cent during the three years of FLD program, which showed the efficacy of technical interventions. This will accelerate the adoption of technological intervention to increase the yield performance of soybean.

Table.1 Productivity, technology gap, extension gap and technology index of soybean under FLDs

\begin{tabular}{|c|c|c|c|c|c|c|c|c|c|}
\hline \multirow[t]{2}{*}{ Year } & \multirow{2}{*}{$\begin{array}{l}\text { Area } \\
\text { (ha) }\end{array}$} & \multirow{2}{*}{$\begin{array}{l}\text { No. of } \\
\text { Demo }\end{array}$} & \multicolumn{3}{|c|}{ Yield (kg/ha) } & \multirow{2}{*}{$\begin{array}{c}\% \\
\text { increase } \\
\text { over FP }\end{array}$} & \multirow{2}{*}{$\begin{array}{l}\text { Technology } \\
\text { gap (kg/ha) }\end{array}$} & \multirow{2}{*}{$\begin{array}{c}\text { Extension } \\
\text { gap } \\
(\mathrm{kg} / \mathrm{ha})\end{array}$} & \multirow{2}{*}{$\begin{array}{l}\text { Technology } \\
\text { index }(\%)\end{array}$} \\
\hline & & & Potential * & IP & FP & & & & \\
\hline 2014-15 & 5 & 12 & 2000 & 1820 & 1500 & 21.33 & 180 & 320 & 9.00 \\
\hline 2015-16 & 5 & 12 & 2000 & 1360 & 976 & 39.00 & 640 & 384 & 32.00 \\
\hline 2016-17 & 5 & 12 & 2000 & 1733 & 1439 & 20.58 & 267 & 294 & 13.35 \\
\hline \multicolumn{3}{|c|}{ Average } & 2000 & 1638 & 1305 & 26.97 & 362 & 333 & 18.11 \\
\hline
\end{tabular}

Table.2 Economic evaluation of demonstrated package of practices

\begin{tabular}{|c|c|c|c|c|c|c|c|c|c|}
\hline \multirow[t]{2}{*}{ Year } & \multirow{2}{*}{$\begin{array}{l}\text { No. of } \\
\text { Demonst } \\
\text { ration }\end{array}$} & \multicolumn{2}{|c|}{$\begin{array}{c}\text { Gross Expenditure } \\
\text { (Rs/ha) }\end{array}$} & \multicolumn{2}{|c|}{$\begin{array}{l}\text { Gross return } \\
\text { (Rs/ha) }\end{array}$} & \multicolumn{2}{|c|}{$\begin{array}{c}\text { Net return } \\
\text { (Rs/ha) }\end{array}$} & \multicolumn{2}{|c|}{ B:C Ratio } \\
\hline & & IP & $\mathbf{F P}$ & IP & FP & IP & FP & IP & FP \\
\hline 2014-15 & 12 & 18200 & 17500 & 54600 & 45000 & 36400 & 27500 & 3.00 & 2.57 \\
\hline 2015-16 & 12 & 19650 & 18100 & 43520 & 31232 & 23870 & 13132 & 2.21 & 1.72 \\
\hline 2016-17 & 12 & 25500 & 24850 & 51975 & 43162 & 26475 & 18312 & 2.03 & 1.73 \\
\hline Average & & 21117 & 20150 & 50032 & 39798 & 28915 & 19648 & 2.41 & 2.00 \\
\hline
\end{tabular}

IP -Improved package of practices, FP - Farmers practices

Economic analysis (Table 2) revealed that adoption of improved package of practices required an additional cost of Rs 967 per ha over farmer's practice. This additional cost led to increased average net returns by Rs 9267 per ha, which was higher by about 60 per cent over farmer's practice. The benefit cost ratios of under recommended practices were higher (2.03-3.00) than farmer's practice
(1.72-2.57). This may be due to higher yields obtained under recommended practices compared to farmer's practices. Meena et al., (2011) reported that 23.32 per cent increase in yield under improved technologies was observed over farmers practices, Bhatnagar (2001) reported that the research emanated production technologies were capable of enhancement of productivity of soybean by 
32.26 per cent through frontline demonstration. Similarly Raghuwanshi et al., (2009 \& 2010), Badaya et al., (2017) and Singh et al., (2019) also observed enhancement in the productivity of soybean by adoption of improved technology over farmers practices.

In conclusion on the basis of the study it may be concluded that the yield was higher on FLD plots as compared to farmers' practise. Also the farmers can earn more from the cultivation of demonstrated variety instead of local check. Scientific method reduces technology gap and increases productivity. Hence, technical support should be provided to the farmers through different extension methods to reduce extension gap In nutshell, the result of front line demonstrations on the package of practices suggested that by its adoption, the farmers can realize higher yields and net profit in soybean cultivation.

\section{References}

Ajeet Singh, Bhupendra Singh, Monika Jaiswal and Kartikey Singh. 2019. Yield gap analysis of soybean through front line demonstration in Burhanpur district of Madhya Pradesh. Journal of Pharmacognosy and Phytochemistry. SP5: 29-31.

Badaya A.K., S.S. Chauhan, SS Dhakad and G.S. Gathiye (2017). Exploring Livelihood Security through Enhancement of Soybean Production on Farmer's Field of Dhar District of M.P. International Journal of Agricultural Sciences, 13 (1): 101-106

Bhatnagar P. S., 2009. Harnessing productivity and profitability potentials of soybean (Glycine max) for its sustainability in India. In: Abstracts: Developing a Global soy blueprint for a Safe, Secure and Sustainable Supply, WSRC. 2009, August 10-15, Beijing,
China, pp.209

Bhargava KS, Khedkar NS, Nayak MP, Umat Rajiv and Ambawatia GR. 2015. Assessment of Front Line Demonstrations on soybean in Shajapur district of Madhya Pradesh. Soybean Research. 13(2): 60-64.

Choudhary BN. 1999. Krishi Vigyan KendraA guide for KVK Managers. Publication of Division of Agricultural Extension, ICAR. Pp: 73-80.

Gautam US, Paliwal D, Kumar Nirmal. Impact of Front line Demonstration on Soybean production to improved livelihood of farmers in Madhya Pradesh. Compendium, 4th National Ext. Edu. Congress, 2007, 139-140.

Kadian KS, Sharma R and Sharma AK. 1997. Evaluation of front line demonstration trials on oilseeds in Kangra valley of Himachal Pradesh. Annals of Agricultural Research. 18:40.

Meena, D.S., M. Ali, B. Ram, and Tetarwal, J.P. 2012. Impact of Improved Technology on Soybean Productivity in South Eastern Rajasthan Soybean Research 10: 99 - 103

Raghuwanshi, S. R. S., O. P. S. Raghuwanshi, R. Umat, G. R. Ambawatia and Bhargav, K. S. 2009. Impact of Improved Technologies on Soybean Productivity. Haryana Journal Agronomy 25(1\& 2): 82- 3 .

Raghuwanshi, S. R. S., O. P. S. Raghuwanshi, R. Umat, G. R. Ambawatia and Bhargav, K. S. 2010. Productivity enhancement of soybean (Glycine max (L.) Merrill) through improved technology in farmers field. Soybean Research 8: 85-88.

Singh Anuj Kumar, SB Agrawal, BS Kirar, TR Sharma, Anay Rawat and Mohammad Imran Khan. 2018. Impact of production technology on productivity and profitability of soybean under Kymore Plateau and Satpura hills 
Agro Climatic zone of Madhya Pradesh. The Pharma Innovation Journal. 7(10): 82-84.

SRK Singh, Anupam Mishra, Alok Suryawanshi and Varsha Shrivastava. 2019. Effect of varietal intervention on the yield of soybean crop across agroclimatic zones in Madhya Pradesh: A cluster approach. Journal of Pharmacognosy and Phytochemistry. 8(2): 408-410.

\section{How to cite this article:}

Khedkar, N. S., S. S. Dhakad, Chandrika Sharma, Gayatri Verma, R. F. Ahirwar and Ambawatia, G. R. 2020. Impact of Front Line Demonstration on the Yield and Economics of Soybean crop in Shajapur District of Madhya Pradesh, India. Int.J.Curr.Microbiol.App.Sci. 9(08): 1768-1772. doi: https://doi.org/10.20546/ijcmas.2020.908.204 